\title{
EXCESSIVE REQUIREMENT FOR HEPARIN DURING CARDIAC SURGERY
}

\author{
Frances Chung, Tirone E. David and J. Watt
}

\begin{abstract}
A case of excessive heparin requirement during cardiopulmonary bypass is reported. A patient with sepsis secondary to a myocardial abscess required $13.5 \mathrm{mg} \cdot \mathrm{kg}^{-1}$ of heparin to increase his activated coagulation time to a therapeutic level. This phenomenon might be due to individual variability, lupus vasculitis, septicaemia, repeated thromboembolic phenomenon with hypercoagulable state, or chronic disseminated intravascular coagulation with partial antithrombin deficiency.
\end{abstract}

KEY WORDS: CARDiaC SURGERY; Heparin, excessive requirement.

ACTIVATED COAGULATION TIME (ACT) was first described by Hattersly.' It has been recommended as a monitor of heparin levels during cardiopulmonary bypass. ${ }^{2,3}$ This would prevent intra-operative clotting, ${ }^{4}$ excessive anticoagulation and inadequate neutralization of heparin by protamine. ${ }^{5-8}$ Recently, we encountered a case of heparin resistance during cardiac surgery.

\section{CAse Report}

A sixty-eight year old man was hospitalized because of fever, anorexia, weight loss and weakness of four weeks duration. He had a past history of anterolateral myocardial infarction complicated by left ventricular aneurysm three years before admission. Blood cultures grew Camphylobacter intestinalis, which was sensitive to ampicillin and tobramycin. He was treated with both antibiotics. He was also found to have lupus erythematosus. Ten days after admission he suddenly had an arterial embolism to his left leg, which required embolectomy. Two days later he cleveloped signs of an acute abdominal problem and a laparotomy was done. Cholecystectomy and splenectomy were done because the gall bladder was thought to be the source of the sepsis and the spleen contained a septic infarct. Six days post-laparotomy his right leg developed deep venous thrombosis. He was not heparinized because of the possibility of septic emboli to the cerebrum, or lupus cerebritis manifested by intermittent periods of confusion and one

Frances Chung, M.B., B.S., F.R.C.P.(C), Lecturer, Department of Anaesthesia; Tirone E. David, M.D., F.R.C.S.(C), Assistant Professor of Surgery; J. Watt, M.D., F.R.C.P.(C), Associate Professor of Haematology; University of Toronto and Toronto Western Hospital, 'Toronto, Ontario, Canada.

Canad. Anaesth. Soc. J., vol. 28, no. 3, May 1981 grand mal seizure. He continued spiking fever. Two dimensional echocardiography was suggestive of a large thrombus in the ventricular aneurysm, and cardiac catheterization was then done. Because of persistent fever and multiple arterial emboli, the diagnosis of infected left ventricular thrombi was made. Cardiac surgery was then done.

Pre-operatively the coagulogram showed PT $10.9 \mathrm{sec}$ (control $10.9 \mathrm{sec}$ ) a shortened PTT of $26.1 \mathrm{sec}$ (control $35.25 \mathrm{sec}$ ), platelet count 494,000 per $\mathrm{mm}^{3}$, rough fibrinogen normal at $295 \mathrm{mg}$ per cent, thrombin time $13.8 \mathrm{sec}$ (control $12.8 \mathrm{sec}$ ), fibrin split products increased to $120-140 \mu \mathrm{g} / \mathrm{ml}$ (control $<10 \mu \mathrm{g} / \mathrm{ml}$ ). General anaesthesia was induced uneventfully. Baseline ACT was 103 seconds. The patient's weight was $64 \mathrm{~kg}$. Ten thousand units $\left(1.5 \mathrm{mg} \cdot \mathrm{kg}^{-1}\right)$ of heparin were given. Repeated ACT was surprisingly low at 118 seconds. Ten thousand units (total $3 \mathrm{mg} \cdot \mathrm{kg}^{-1}$ ) were given. The resulting ACT was only 215 seconds. Large doses of heparin were given repeatedly (Table I), according to the heparin ACT dose response curve (Figure 1) before a satisfactory ACT above $400 \mathrm{sec}$ was achieved.

The left ventricular aneurysm was found to contain a purulent abscess. Apical clots and intraventricular organized thrombus were removed and the left ventricular aneurysm was excised. The ventriculotomy was repaired with monofilament sutures over two strips of pericardium. The patient was weaned from cardiopulmonary bypass without difficulty. Total bypass time was 58 minutes. Heparin was reversed with $450 \mathrm{mg}$ of protamine with the ACT returning to $120 \mathrm{sec}$. The patient did well post-operatively and remains asymptomatic and afebrile six months after his left ventricular resection. 
TABLE 1

The Dosage Requirements of Heparin Before Bypass and DURING BYPASS

\begin{tabular}{cccl}
\hline Time* & Heparin (units) & Total Dosage & ACT (seconds) \\
\hline- & 10000 & $10000\left(1.5 \mathrm{mg} \cdot \mathrm{kg}^{-1}\right)$ & 103 (control) \\
- & 10000 & $20000\left(3.0 \mathrm{mg} \cdot \mathrm{kg}^{-1}\right)$ & 215 \\
- & 10000 & $30000\left(4.5 \mathrm{mg} \cdot \mathrm{kg}^{-1}\right)$ & 238 \\
- & 15000 & $45000\left(7.5 \mathrm{mg} \cdot \mathrm{kg}^{-1}\right)$ & 346 \\
$5 \mathrm{~min}$ & $10000+5000$ & $60000\left(10 \mathrm{mg} \cdot \mathrm{kg}^{-1}\right)$ & 338 \\
$9 \mathrm{~min}$ & 15000 & $75000\left(12 \mathrm{mg} \cdot \mathrm{kg}^{-1}\right)$ & 450 \\
$18 \mathrm{~min}$ & 8000 & $83000\left(13 \mathrm{mg} \cdot \mathrm{kg}^{-1}\right)$ & 375 \\
$35 \mathrm{~min}$ & 3000 & $86000\left(13.5 \mathrm{mg} \cdot \mathrm{kg}^{-1}\right)$ & 404 \\
$52 \mathrm{~min}$ & - & - & 495 \\
\hline
\end{tabular}

*Times shown are after bypass.

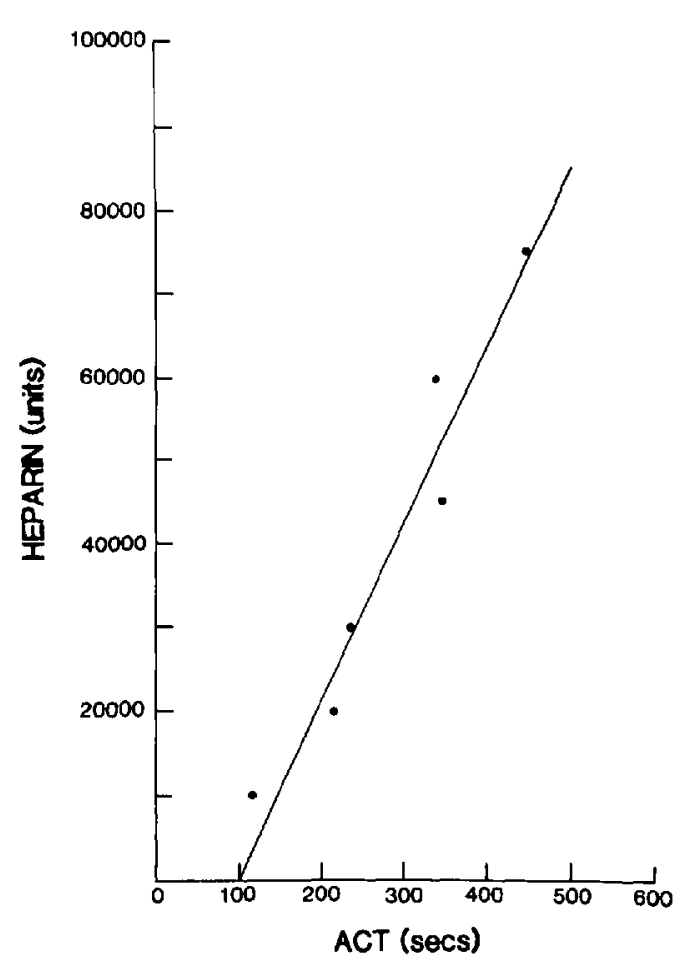

FIGURE 1 Heparin-ACT dose response graph.

\section{Discussion}

The biological actions of heparin, a sulphated mucopolysaccharide, depend on antithrombin neutralizing thrombin, forming a 1:1 stoichiometric enzyme inhibitor complex. ${ }^{9}$ It also accelerates the inactivation of coagulation factors $\mathrm{Xa}$, IXa, XIIa and possibly VIIa, and enhances the activation of plasmin by antithrombin.

The volume of distribution of heparin is limited to the plasma volume. Heparin has a very short half-life, about 1.5 hours, which is dose dependent. It is not eliminated enzymatically, nor by glomerular filtration and renal tubular secretion.
The anticoagulant is transferred to reticuloendothelial cells, which may provide the means for its degradation. The amount of heparin required to produce an arbitrary prolongation in the clotting time has been shown to vary threefold from patient to patient. ${ }^{2}$ The rapidity with which the administered heparin disappears from the blood may vary fourfold. ${ }^{2}$

In our patient excessivcly large amounts of heparin (13.5 $\left.\mathrm{mg} \cdot \mathrm{kg}^{-1}\right)$ were required to establish an adequate ACT for cardiopulmonary bypass. There is an individual variation in heparin requirement. ${ }^{10}$ Patients with coronary artery disease may have increased heparin resistance. ${ }^{11}$ Our patient had lupus vasculitis, deep vein thrombosis, repeated embolization to the leg and spleen, and thrombocythaemia probably secondary to splenectomy. These clinical entities have all been shown to be refractory to heparin therapy. ${ }^{12}$

The observed hypercoagulability in our patient might have been due to the septicaemia and endocarditis. The following mechanisms of hypercoagulation in sepsis have been identified: activation of platelets, disseminated intravascular coagulation, reduced antithrombin III, and binding of heparin by antibiotics. ${ }^{13.14}$

Campylobacter intestinalis is an infrequent cause of human infection, with fewer than 100 cases reported in the medical literature. ${ }^{15}$ It is a gram-negative bacillus. Although it has been a recognized animal pathogen, the route and source of infection in man remain unknown. Predisposing factors include immunosuppressive therapy, alcoholism, cardiac diseases, and hepatorenal disorders. Endocarditis due to this organism is rare. Only 13 cases have been observed and reported. ${ }^{16}$ The symptoms of Campylobacter intestinalis endocarditis are insidious, of long duration, and non-specific; fever is the only constant finding. The selection of antibiotic ther- 
apy must rest on in vitro sensitivity studies. It has been successfully treated with erythromycin, ampicillin, tetracyline, clindomycin, gentamycin, and a combination of penicillin and streptomycin. In our case, antibiotic treatment was not effective because of the abscess formation in the left ventricular aneurysm.

The patient underwent his cardiac surgery shortly after two major operations. Hypercoagulability is also seen after surgery: plasma antiheparin factor increases and fibrinolytic activity of plasma is inhibited. ${ }^{17}$

Our patient may have had chronic disseminated intravascular coagulation with thrombotic phenomenon dominating over haemorrhagic phenomenon. In some patients with disseminated intravascular coagulation, antithrombin concentration is reduced to less than 10 per cent of normal. In antithrombin deficiency, the adminstration of heparin has little effect on prolonging clotting time and the infusion of fresh plasma or antithrombin concentrates and heparin can restore its effectiveness. ${ }^{18}$

In summary, a multitude of factors may have been operative in creating this patient's resistance to heparin. We could not establish the final reasons. However, this case enforces the recommendation of routine monitoring of ACT during cardiac and vascular surgery.

\section{REFERENCES}

1. Hattersley, P.G. Activated coagulation time of whole blood. J.A.M.A. 196: 436-440, 1966.

2. Bull, B.S., Korpman, R.A., Huse, W.M., et al Heparin therapy during extracorporeal circulation: I. Problems inherent in existing heparin protocols. Thorac. Cardiovasc. Surg. 69: 674-684, 1975.

3. Bull, B.S., Huse, W.M., Braver, F.S., et al. Heparin therapy during extracorporeal circulation. II. The use of a dose response curve to individualize heparin and protamine dosage. J. Thorac. Cardiovasc. Surg. 69:685-689, 1975.

4. MABRY, C.D., READ, R.C., Thompson, B.W., et al. Identification of heparin resistance during cardiac and vascular surgery. Arch. Surg. 114: 129-134, 1979.
5. Doty, D.B., KNotT, H.W., Hoyt, J.L., et at. Heparin dose - response for accurate anticoagulation in Cardiac Surgery. J. Cardiovasc. Surg. 20: 597-604, 1979.

6. YounG, J.A., Kisker, C.T. \& Doty, D.B. Adequate anticoagulation time during cardiopulmonary bypass determined by activated clotting time and the appearance of fibrin monomer. Ann. Thorac. Surg. 26: 231-240, 1978.

7. Babka, R., Colby, C., El-Etr, A., ef al. Monitoring of intraoperative heparinization and blood loss following cardiopulmonary bypass surgery. J. Thorac. Cardiovasc. Surg. 73: 780-782, 1977.

8. Verska, J.J. Control of heparinization by activated clotting time during bypass with improved post-operative haemostasis. Ann. Thorac. Surg. 24: 170-173, 1977.

9. Estes, J.W. Clinical pharmacokinetics of heparin. Clinical pharmacokinetics, 5: 204-220, 1980.

10. Hill, J.D., Dontigny, L., Deleval, M., ef $a !$. A simple method of heparin management during prolonged extracorporeal circulation. Ann. Thoras. Surg. 17: 129-134, 1974.

11. Svehla, C. Heparin resistance in patient with Coronary artery disease. Atherosclerosis $18: 509-$ S12, 1973.

12. Coon, W. Heparin. A drug of varying composition and effectiveness. Clinical pharmacology and Therapeutics 23: 139-142, 1978.

13. Corrigan, J.J., Jr., Ray, W.L. \& MaY, N. Changes in the blood coagulation system assor ciated with septicaemia. N.E.J.M. 279: 851-856, 1968.

14. Nelson, R.M., Frank, C.G. \& Mason, J.O. The antiheparin properties of the antihistamines, tranquilizer and certain antibiotics. Surg. Forum, 9 : $146-150,1958$.

15. Gubina, M., Zajc-Satler, J., Mehle, J., et a!. Septicaemia and meningitis with Campylobacter fetus subspecies intestinalis. Infection, 4: 115-118, 1976.

16. Wozniak, R., Middleton, J., Chmel, H., Cruz, C. \& Young, R. Gram-negative endocarditis caused by Campylobacter fetus. South Med. J. 7i: (10): $1311-1312,1978$.

17. Farbiszewski, R., Lipinski, B. \& Lebenstein, $W$. Plasma antiheparin activity soluble fibrin monomer complexes and fibrinolysis in plasma of patients after surgery. Thromb. Diath. Haemorrh. 22: 408-410, 1969.

18. RosenberG, R.D. Actions and interactions of antithrombin and heparin. N.E.J.M.292: 146-151, 1975.

\section{RÉSUMÉ}

Les auteurs rapportent le cas d'un malade ayant requis des doses très importantes d'héparine pour atteindre des niveaux thérapeutiques au cours d'une circulation extracorporelle. Ce patient hospitalisé en septicémie avec un abcès myocardique a subi une resection d'anévrysme ventriculaire avec résection de thrombi ventriculaires. On a dû administrer une dose totale d'héparine de $13.5 \mathrm{mk} \cdot \mathrm{kg}^{-1}$ pour atteindre une héparinisation adéquate pour la circulation extra-corporelle.

On a retenu plusieurs facteurs pouvant expliquer le phénomène dans ce cas particulier à savoir: la possibilité d'une variation individuelle de la sensibilité à l'héparine, la présence d'une vasculite à lupus, l'état de septicémie du malade, les épisodes emboliques répétés (avec un état d'hypercoagulabilité) survenus chez ce patient ou, enfin une coagulation intravasculaire chronique avec activité antithrombique déficiente. 